Pakistan Journal of Education

Vol.38, No.1, 2021, 17-37

\title{
Etiology of Students Fail to Complete Doctorate Degree within Stipulated Time
}

\author{
Muhammad Irshad*
}

\begin{abstract}
In the face of contemporary world requirements, the demand for a research degree is highly aggravated. In order to fulfill the growing demand academia enrolled candidates with such distinctive characteristics like self-motivated, long studying/working stamina coupled with strong family support. The failures of such distinguish characteristics students postulate long-lasting effect on society in general and academia in particular. This study was conducted to identify factors that affect research students' performance with regard to the timely completion of a research degree. Students enrolled for a research degree in KPK universities were considered population i.e. 963 and a stratified sampling technique was used for sample selection. Total 275 questionnaires were distributed to the respondents and 246 were received back. AMOS-24 and SPSS-20 software were used for analysis that includes EFA, CFA and SEM. The study found that individual background-cum-personal traits, advisor support and organization support are the factors affecting students' performance. Further found a significant positive relationship between identified factors and research degree completion. All stakeholders play their role to support research scholars and educational institutes arrange training sessions for advisors also monitor their schedules and not engage them in teaching activities. Equipped research lab/centers with advanced technologies and ensure access to research students. The criteria of HEC in terms of advisor v/s scholars' ratio may also be maintained. Further research studies may be conducted to examine other host factors affecting research students' performance in different contents and contexts.
\end{abstract}

Keywords: research degree, student performance, individual background and advisor support

Institute of Business Studies, Kohat University of Science and Technology, Kohat. Email: mikhaans@gmail.com 


\section{Introduction}

In academia, a research degree is amiably accredited the highest qualification. Generally students with vivid backgrounds coupled with a desire to pursue research careers in order to contribute to socio-cultural development. The roots of research degree traced back to the nineteen century and Friedrich Wilhelm University, Berlin (Germany) awarded the first degree with title of PhD (Park, 2007). Adopted by the United States and the Yale University of North America awarded PhD degree to James Morris Whiton on studying one year's coursework and six pages dissertation (Cude, 2001; Frank, 2003). Pursued to Yale University PhD degree program initially offered by world top class varsities, however, within a short span of time research degree program started across the world including Pakistan (Cude, 2001). To date, similar criteria for the award of $\mathrm{PhD}$ degree is followed as instituted by Yale University with slight modification according to geographical and discipline demand (Buhanan \& Herubel, 1995). Confronted to the high demand for a research degree in late 1970 the world-leading universities admitted a substantial number of candidates in research degree however, a sophisticated number of enrolled students were dropout and unable to complete the degree (Dressel \& Thompson, 1977). The dropout ratio of research students' postulate challenge for academia that how to fulfill research degree growing demand. According to Bowen and Rudenstine (1992), about 50\% of students enrolled for a research degree in American University were unable to complete including $20 \%$ of those students who have fulfilled all the degree pre-requisites but unable to finalized research work.

In 1900 after the establishment of the Association of American Universities doctorate students discouragement revealed aggravated with depletion of resources wastages (individual, institutional and government resources) (Kluever, 1995). The research concludes the excuses of dropout students include supervisor support, learning environment, lack of allied facilities (Rogers, 1969). Literature further highlights that performance of research degree students are evaluated through "completion time (Gravois, 2007). The Council of Graduate Schools claims that over the decade only $57 \%$ of research students successfully complete the degree requirements (CGS, 2017; Vidak et al., 2017). Despite, the dropout v/s success data of research degrees neither maintained at university level nor country level as well as published kinds of stuff is not available for example, Canadian universities data are not maintained at any level (Elgar, 2013). Statistics highlight that $75 \%$ of doctorate students of UK universities failed to complete their degree within four years tenure (HEFCE, 2010). Moreover, out of enrolled students at the University of Split School of Medicine, 
Croatia only $11 \%$ completed a doctorate degree from 1999 to 2011 (Vidak, et. Al., 2017). According to Baird (1990), about $50 \%$ of research students unable to complete the degree and the figure noticed greater in a certain discipline. The research degree completion ratio in STEM students are higher compared to their counterpart humanities discipline (Gravois, 2007). Moreover, women attrition rates were found higher than men (Smallwood, 2004) and the Americans dropped-out rate was found 8\% higher than foreigners in the last five years (Smallwood, 2004). It is further concluded that research degree completion time has significantly increased during the last two decades (Bowen \& Rudenstine, 1992). This substantial dropout ratio of research students' postulate challenge for academia as self-motivated and scholastically outstanding candidates seeks admission in a research degree (Stankov, Morony \& Lee, 2014; Vidak, et. Al., 2017). Literature highlight that candidates with profound supervisor support augmented with institutional background relatively low rate of dropout noted early completion of degree (Bagaka et al., 2015). Nevertheless, several factors found influence affecting timely completion of a research degree that may comprise; supervisor support, personal attachment, learning environment, institutional regulation/support etc. (van de, Yerkes, Mouw \& Sonneveld, 2013).

\section{Development of Research Hypotheses}

Literature revealed that across the world varsities introduce countless scholarships and other financial-cum-non financial incentives to motivate students to take admission in research degree also encouraged to strive for timely completion (Halbert, 2014). The author further added that research students demand freedom and flexibility in order to effectively manage resources and efficiently complete tasks (Halbert, 2014). Various factors influence research student performance like advisor support, financial resources, research area \& topic and research training (Association for Support of Graduate Students, 1993; Ramos, 1994; Tluczek, 1995). According to Smith (2000), research students belong to age group 30-40 years either married or in relationships and live far away from research centres in order to utilize resources as well as occasionally meet with research advisors and about $70 \%$ of doctorate students engaged in non-discipline works. According to Wao et al., (2011) research writing skill is an internal factor affecting the performance of research students whereas, family support has found external factor. Further, strengthen by Pinson (1997) found a significant relationship between research writing skill, time and doctorate degree completion. Moreover, Chiappetta-Swanson and Watt (2011) conclude similarly findings whereas Odena and Burgess (2012) revealed that research 
writing skills are an insignificant factor for doctorate degree completion as compare to subject knowledge. In this regard, no solo factor is to be considered responsible that affect research students' performance (Wao et al., 2011). There is a lack of empirical study augmented with constructive debate on causes of timely completion of research degree high attrition rate of a doctorate degree (Cude, 2001; Kerlin, 1995). Considering the above, this research study was conducted to conclude the factors affecting the performance of research students toward timely degree completion. Carter, (2004) conclude that research students' performance can be measured in term of timely degree completion. Numerous factors comprehended by literature that affect research students' performance includes individual background/personal traits, advisor support and resource management skills (Kuh et al., 2005; McClenney, 2013; Nasr \& Jackson-Harris, 2016; Tovar, 2015).

\section{Student's Background-cum-Personal Traits}

Individual background plays a vital role in the performance and considered a crucial factor of success (Sellman, Born, Stricland, \& Ross, 2010). According to Palmer (2009), there is a direct relationship between individual background to cope with depression and research degree completion. Further studies revealed student background play a positive role in degree completion (Cotterall 2013; Ramos, 1994; Tluczek, 1995). According to Fosse et al., (2015) there is a significant relationship between individual background and performance further strengthened by studies that individual self-belief boosts performance (Caprara, et al., 2011). Bandura, (2012) argue that individual self-efficacy has a significant positive association with behaviour development. Research studies revealed individual self-efficacy level has a significant impact on students' performance (Barrick et al., 2001; Judge et al., 2002; 2007; Poropat, 2009; Richardson et al., 2012). Student performance has greatly affected by individual conscientiousness (Barrick, Mount, \& Judge, 2001; Caprara et al., 2011; Poropat, 2009) a component of motivation, stamina, goalsetting, expectancy and inspiration (Judge et al., 2002; Tabak et al., 2009). The individual background and personal traits play a significant role in performance by providing a congenial environment (Dinther et al., 2011; Feyter et al., 2012; Poropat, 2009). Considering the above, the following research hypothesis developed:

$\mathrm{H}_{1}$ : There is a statistically significant positive relationship between individual background / personal traits and research degree completion. 


\section{Advisor Support}

Research students' supervision is a dominant factor in teaching and research supervisor knowledge and support play a vital role in timely research completion (Afzal et al., 2019). According to Knowles (1999), research supervision is a "critical conversations part of learning" it is regarded as mentorship higher than teaching (Taylor, 1995). The role of a research advisor is not yet cleared, advisors only guide students which the replication of the pedagogy technique of teaching (Ellinger, Ellinger, \& Keller, 2003). As Baloyi et al., (2014) claim that research supervisors play a similar role as managers in the business. It is due to a lack of understanding approach with regard to the role of advisor in research degree completion (Pearson \& Kayrooz 2005). Gurr (2001) found good relation with an advisor and an agreeable concept has a positive impact on students' performance. Further, strengthen by Halbert (2014) that supervisor relation has found a significant factor of research student performance. Research students liked to work with a supportive, flexible and responsive advisor and an advisor with a positive attitude found compassion, enthusiasm and grant access to expertise networks (Halbert, 2014). There is a strong positive association between advisor support and students performance (Paltridge \& Woodrow 2012). Studies recommend that advisor must comprehend their research students in terms of pedagogy support and develop their capabilities (Cotterall, 2013; Paltridge \& Woodrow 2012). Wisker et al. (2010) advisor support have a significant positive impact on student performance also boost their confidence as well as develop students research writing abilities for timely completion of a research degree (Wang \& Yang 2012). Further, strengthen by Smith (2009), found advisor encouragement has a direct correlation with performance. Considering the above, the following research hypothesis developed:

$\mathrm{H}_{2}$ : There is a statistically significant positive relationship between advisor support and research degree completion.

\section{Organization Support}

In academia organizational support referred to the support of educational institutes that extend to particular students in terms of resources provision and utilization. This term derived from perceived organization support (POS) theory. According to this theory workers perceived for organization support in terms of growth, development and betterment has found a positive impact on workers performance (Baran, 
Shanock, \& Miller, 2012; Sumathi, Kamalanabhan, \& Thenmozhi, 2015). Similarly, in academia, the organization support surely affects the performance of research students. The organizational support has divided into two heads a) tangible support like equipment, lab, space and finance etc. b) intangible support comprised freedom, encouragement, authority, acknowledgement and self-esteem etc. (Neves \& Champion, 2015). There is a low rate of attrition in an organization with an image of positive support leads to mollify negative behaviours (Allen \& Shanock, 2013). Further found a positive association between fair play policy and performance (Dejoy et al., 2010). Organizational leadership has considered responsible for students performance (Stelnicki, Nordstokee \& Saklofske 2015) as supportive leaders comprehend student needs and take favourable initiatives that enrich success rate (Shumaker \& Wood 2016). The application of fair and favourable policies encourages students for timely completion (Brooks et al., 2013; Campbell et al., 2012). Supportive learning environments boost students' performance (Felten et al., 2016; Lei 2016). In academia, organizational support stimulates students to optimally utilize their potential in order to boost academic performance (Felten et al., 2016). Considering the above, the following research hypothesis developed:

$\mathrm{H}_{3}$ : There is a statistically significant positive relationship between organizational support and research degree completion.

\section{Research Problem Statement}

Indeed the research degree is amiably accredited as the highest degree in academia and generally highly motivated students with vivid academic background, long studying/working stamina, strong family support coupled with auspicious personal traits seeking admission in this degree program. In the face of globalization and technological advancement, the demands for research students are aggressively high and in order to 22ulfil the growing demand, academia enrolled students with such distinctive characteristics. However, when such distinguish characteristics students failed to complete the degree within given timeframe postulate questions for academia, sponsors, policymakers and government. As the attrition rate of research degrees across disciplines found aggressively high (Kang, 2004) and the woman dropout ratio aggravated than men (Smallwood, 2004). In this regard, there is a need to identify factors that affect research students' performance with regard to the timely completion of a research degree. 


\section{Research Objectives}

Following research objectives are formulated for this study:

(a) To identify factors affecting the performance of research students in terms of timely completion of a research degree.

(b) To exam the impact of identified factors on students' performance

(c) To put forward suggestions based on research findings.

\section{Research Methodology}

Apropos, this research study was conducted to articulate factors affecting research students' performance in terms of timely degree completion. This study is quantitative in nature and students enrolled for a research degree in Khyber Pakhtunkhwa, Pakistan charted universities were considered population. However, due to time and financial constraints research was limited to universities operated in the capital of Khyber Pakhtunkhwa (i.e. Peshawar). A list of students enrolled for a research degree in selected universities was obtained. Population size was 963 and sample size was 275 as per Israel (1992) with a 5\% margin of error. A stratified sampling technique was used for sample selection. Total 275 questionnaires were distributed to the respondents and 246 were received back. AMOS-24 and SPSS-20 software were for data analysis.

\section{Measurements Scale}

The required data for this study were collected through a survey questionnaire based on five Likert scales from strongly disagree to strongly agree. The measurement scales were adopted from existed literature (Baloyi, Waveren, \& Chan, 2014; Halbert, 2014; Neill, 2016; Slight, 2017) and modified according to local conditions.

\section{Data Analysis and Results}

Exploratory Factor Analysis (EFA) followed by Confirmatory Factor Analysis (CFA) was applied to establish the validity of the questionnaire and research model. Reliability was checked through Cronbach's alpha. Composed variables values are $\alpha=0.972>0.7$ (acceptable range). Consequently the individual variable value of Individual background $\alpha=.962$, advisor support $\alpha=.947$ and organization support $\alpha=.910$ greater than suggested values (Gliem \& Gliem, 2003). 


\section{Demographic Details}

Below table presents the demographic detail of respondents along with percentage and cumulative percentage. The table shows that 52 respondents belong to the age group up to 25 years, 125 belong to 26-35 years, 40 belong to $36-45$ years and only 29 respondents are 46 years and above. Moreover, 187 respondents are male and 59 are female similarly 133 are married and 133 respondents are unmarried.

Table 2

Respondents Demographic detail

\begin{tabular}{llccc}
\hline Description & Variable(s) & Frequency & Percent & $\begin{array}{c}\text { Cumulative } \\
\text { Percent }\end{array}$ \\
\hline \multirow{3}{*}{ Age } & Up to 25 years & 52 & 21.1 & 21.1 \\
& 26 to 35 years & 125 & 50.8 & 71.9 \\
\multirow{4}{*}{ Gender } & 36 to 45 years & 40 & 16.3 & 81.2 \\
& 46 years and above & 29 & 11.8 & 100.0 \\
\multirow{3}{*}{ Marital status } & Male & 187 & 76.1 & 76.1 \\
& Female & 59 & 23.9 & 100.0 \\
& Married & 133 & 54.1 & 54.1 \\
& Unmarried & 113 & 45.9 & 45.9 \\
\hline
\end{tabular}

\section{Exploratory Factor Analysis}

Exploratory factor analysis was applied to examine the grouping of items hanging together. The level of construct (i.e. factorial) validity within the dataset was also determined through EFA. The main purpose of EFA is to hang together similar items also determine the ample number of factors for the proposed model.

Table 3

KMO and Bartlett's Test

\begin{tabular}{lcc}
\hline Kaiser-Meyer-Olkin Measure of Sampling Adequacy. & & .768 \\
\hline & Approx. Chi-Square & 25953.202 \\
Bartlett's Test of Sphericity & Df & 450 \\
& Sig. & .001 \\
\hline
\end{tabular}

Kaiser-Meyer-Olkin (KMO) test was applied to establish an ample amount of items envisaging for each factor and evaluate the existence of partial correlations amongst variables (Leech, Barrett \& Morgan, 2005). Above table presents the KMO value .76 and Bartlett test .001 greater than .50 and less than 0.05 suggested vales respectively. Above vales 
significantly satisfied sphericity assumption consequently datasets is found compatible for further analysis.

Table 4

Factor loading and Communalities

\begin{tabular}{|c|c|c|c|c|c|}
\hline & \multicolumn{4}{|c|}{ Component } & \multirow[t]{2}{*}{ Communalities } \\
\hline & 1 & 2 & 3 & 4 & \\
\hline$\overline{\mathrm{IB} 1}$ & .964 & & & & .997 \\
\hline IB 2 & .967 & & & & .907 \\
\hline IB 3 & .967 & & & & .903 \\
\hline IB 4 & .973 & & & & .920 \\
\hline IB 5 & .973 & & & & .921 \\
\hline IB 6 & .971 & & & & .915 \\
\hline IB 7 & .973 & & & & .914 \\
\hline IB 8 & .965 & & & & .902 \\
\hline IB 9 & .939 & & & & .850 \\
\hline IB 10 & .918 & & & & .829 \\
\hline AS1 & & .994 & & & .960 \\
\hline AS2 & & .975 & & & .921 \\
\hline AS3 & & .955 & & & .882 \\
\hline AS4 & & .977 & & & .925 \\
\hline AS5 & & .995 & & & .964 \\
\hline AS6 & & .997 & & & .966 \\
\hline AS7 & & .980 & & & .953 \\
\hline AS8 & & .961 & & & .998 \\
\hline AS9 & & .942 & & & .866 \\
\hline OS1 & & & .980 & & .950 \\
\hline OS2 & & & .894 & & .768 \\
\hline OS3 & & & .809 & & .809 \\
\hline OS4 & & & .981 & & .933 \\
\hline OS5 & & & .911 & & .800 \\
\hline OS6 & & & .948 & & .867 \\
\hline OS7 & & & .992 & & .954 \\
\hline OS8 & & & .980 & & .950 \\
\hline $\mathrm{RDC1}$ & & & & .905 & .982 \\
\hline RDC2 & & & & .966 & .906 \\
\hline RDC3 & & & & .998 & .967 \\
\hline RDC4 & & & & .908 & .976 \\
\hline RDC5 & & & & .999 & .972 \\
\hline RDC6 & & & & .969 & .914 \\
\hline $\mathrm{RDC7}$ & & & & .980 & .955 \\
\hline $\begin{array}{l}\text { Extracti } \\
\text { Rotatio } \\
\text { a. Rotat }\end{array}$ & $\begin{array}{l}\text { Drincip } \\
\text { arimax } \\
\text { ed in } 4\end{array}$ & $\begin{array}{l}\text { Kaiser } \\
\text { ons. }\end{array}$ & $\begin{array}{l}\text { sis. } \\
\text { izatio }\end{array}$ & & \\
\hline
\end{tabular}

Above table show factors loading and communalities values which were found greater than the suggested value i.e. .50 (Leech et al., 2005) and no item was dropped. For 34 items of four variables total of 4 iterations were run. 


\section{Confirmatory Factor Analysis}

As discussed earlier that AMOS software was used for analysis, so prior to using AMOS software assumptions like sample size, data normality and autocorrelation need to be satisfied. The sample size is sufficient and data normality and autocorrelation were checked through skewness and kurtosis test. Statistics satisfied that assumptions as the values of kurtosis and skewness are greater than the suggested value i.e. \pm 2 (George \& Mallery, 2010).

Table 5

Skewness and Kurtosis

\begin{tabular}{lcccc}
\hline Construct & Mean & Std. Deviation & Skewness & Kurtosis \\
\hline Individual background & 2.7370 & 1.89397 & .379 & -1.532 \\
Advisor Support & 2.8392 & 1.64887 & .078 & -1.603 \\
Organization Support & 2.8059 & 1.89295 & .210 & -1.805 \\
Research Degree Completion & 3.0109 & 1.80164 & .099 & -1.867 \\
\hline
\end{tabular}

\section{Measurement Model}

Measurement model validity and reliability were examined through confirmatory factors analysis (CFA). Factor loading values were found greater than suggested value i.e. 0.70 show model is good fitted.

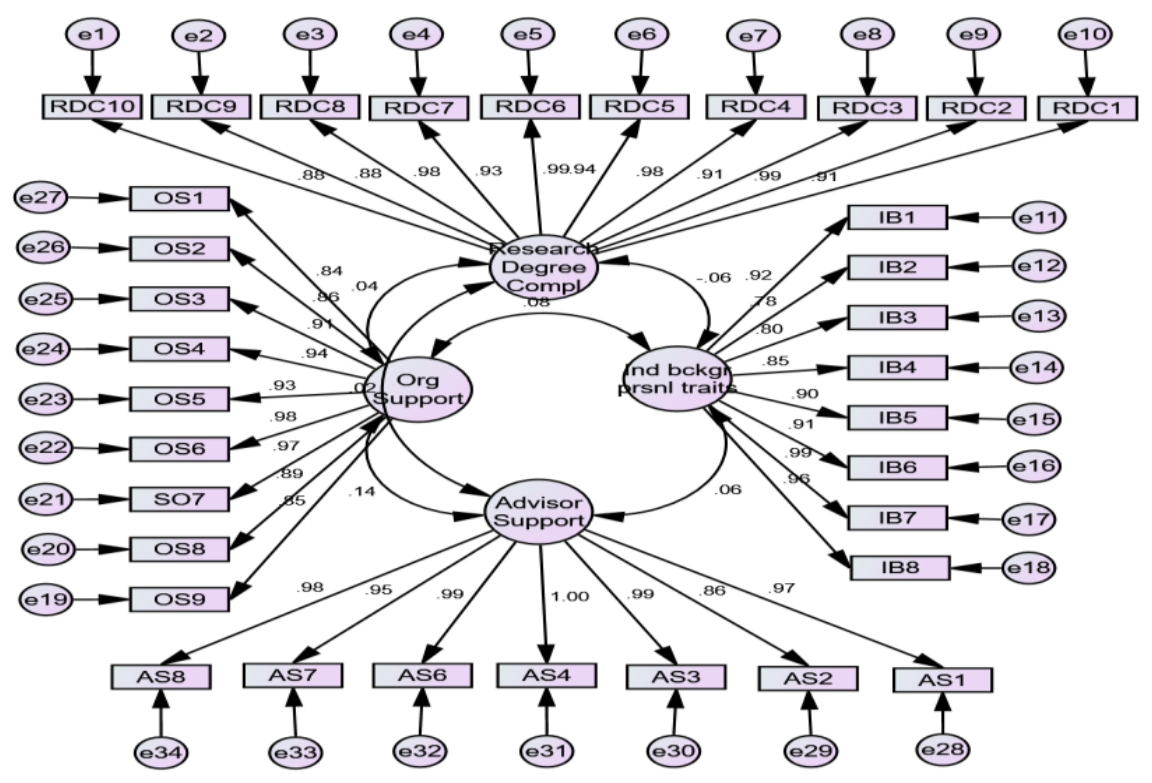


Moreover, model fitness indices were examined and statistical values of model fit indices as shown in below table reflect model is good fitted.

Table 6

Model Fitness Indices

\begin{tabular}{lcc}
\hline Model fit measure & Recommended value* & Measure value \\
\hline Parsimonious Fit Measure & & \\
X2 / df & $\leq 3.00$ & 2.0 \\
RMSEA & $\leq 0.08$ & .06 \\
Absolute Fit Measure & & \\
GFI & $\geq .90$ & .93 \\
AGFI & $\geq .80$ & .90 \\
RMR & $\leq .05$ & .029 \\
Incremental Fit Measure & & \\
CFI & $\geq .90$ & .97 \\
RFI & $\geq .90$ & .89 \\
NFI & $\geq .90$ & .91 \\
TLI & $\geq .90$ & .98 \\
IFI & $\geq .90$ & .93 \\
\hline${ }^{*}$ Hair et al., (2010), Hu and Bentler (1999) & & \\
\hline
\end{tabular}

\section{Model Validity}

Accordingly to Barclay Higgins and Thompson (1995) discriminant, convergent validity and composite reliability need to check before applying SEM. The statistical values of discriminant validity, convergent validity and composite reliability were found acceptable greater than suggested values (Hair et al., 2010; Henseler et al., 2015; Hu $\&$ Bentler, 1999). Furthermore, the values of discriminant validity were greater than the correlation values of the construct with other constructs. Statistics reflect there is no validity concern issues exist in the construct.

Table 7

Validity Statistics

\begin{tabular}{lcccccccc}
\hline & CR & AVE & MSV & MaxR(H) & IB & AS & OS & RDC \\
\hline IB & 0.994 & 0.957 & 0.022 & 1.001 & 0.978 & & & \\
AS & 0.982 & 0.872 & 0.007 & 0.993 & 0.044 & 0.934 & & \\
OS & 0.990 & 0.919 & 0.022 & 0.999 & $0.148^{*}$ & 0.033 & 0.958 & \\
RDC & 0.985 & 0.871 & 0.007 & 0.994 & 0.015 & $*$ & 0.013 & 0.933 \\
\hline
\end{tabular}

$\mathrm{IB}=$ Individual background, $\mathrm{AS}=\mathrm{Advisor}$ Support, $\mathrm{OS}=$ Organization Support, RDC $=$ Research Degree Completion 
HTMT Analysis

HTMT values of the construct were found within acceptable range and highly significant (Henseler et al., 2015).

\begin{tabular}{lllll}
\hline & IB & AS & OS & RDC \\
\hline Individual Background & & & & \\
Advisor Support & 0.045 & & & \\
Organization Support & 0.144 & 0.051 & & \\
Research Degree Completion & 0.018 & 0.049 & 0.035 & \\
\hline
\end{tabular}

\section{Structural Modelling}

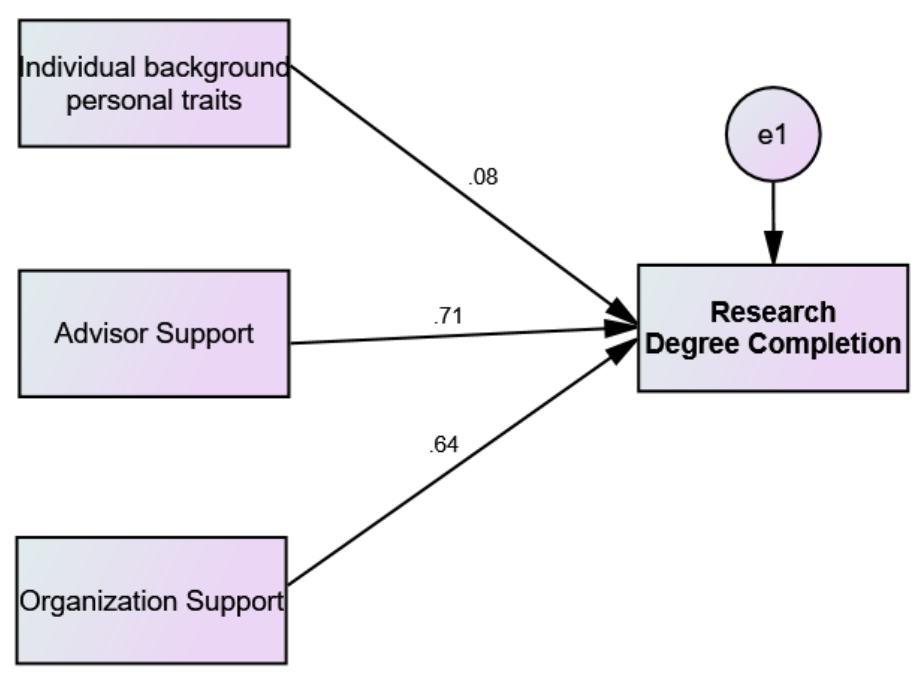

Table 8

Structural Modelling Statistic

\begin{tabular}{|c|c|c|c|c|c|c|c|c|}
\hline & & & & $\begin{array}{l}\text { Estimate } \\
(\beta 1)^{*}\end{array}$ & $\begin{array}{l}\text { Estimate } \\
(\beta 2)^{\star *}\end{array}$ & S.E. & C.R. & $\mathrm{P}$ \\
\hline $\begin{array}{l}\text { Research } \\
\text { Completion }\end{array}$ & Degree & $<--$ & IB & .647 & .366 & .011 & 46.385 & $* * *$ \\
\hline $\begin{array}{l}\text { Research } \\
\text { Completion }\end{array}$ & Degree & $<--$ & AS & .096 & .271 & .010 & 5.821 & $* * *$ \\
\hline $\begin{array}{l}\text { Research } \\
\text { Completion }\end{array}$ & Degree & $<--$ & OS & .719 & .494 & .014 & 48.425 & $* * *$ \\
\hline
\end{tabular}

$* \beta 1=$ Standardized, $\quad * * \beta 2=$ Unstandardized

$\mathrm{IB}=$ Individual background, $\mathrm{AS}=$ Advisor support, $\mathrm{OS}=$ Organization Support 
Structural equation modelling was used to test research hypotheses and accepted based on above table statistics. Table revealed that individual background, advisor support and organization support are positive predictors of research degree completion (as $\beta=.647, .096, .719$; C.R. $=$ $46.385,5.821,48.425$ and $\mathrm{p}=.000<.05$ respectively).

\section{Conclusion}

The demand of research degree highly aggravated in the face of contemporary world requirement. In order to fulfill the growing demand of research students' academia enrolled candidates with such distinctive characteristics like self-motivated, vivid academic background, long studying/working stamina and strong family support coupled with auspicious personal traits. However, the failures of such distinguish characteristics students postulate long-lasting effect on society in general and academia particular as the attrition rate has found high across discipline (Kang, 2004). This study was conducted to identify factors affect research students' performance with regard to timely completion of research degree. For measurement model CFA was applied and model was found good fitted with no validity issue concern consequently structural equation modeling was used to test research hypotheses. Based SEM result all research hypotheses were accepted. Result show that there is significant positive relationship between individual background-cum-personal traits and research degree completion. Research finding is consistent with study of (Daneil et al., 2020; Okesina, 2018; Zhang et al., 2019). Further study found significant positive relationship between advisor support and research degree completion. Research finding is consistent with study of (Afzal et al., 2019; Fan, 2018; Van \& Kroon, 2020). Research study found significant positive relationship between organization support and research degree completion. Research finding is consistent with study of (Edenfield, 2018; Rachmawati et al., 2019; Turabieh et al., 2021). Based on research findings it is recommended that stakeholders play their role to support research scholars in all respect. Educational institutes offering research degree arrange training session for advisor for mentorship also monitor their schedules, meeting with scholars and support extended. Educational institute equipped research lab/centers with advanced technologies also ensure access to research students. Moreover, education institutes not engage research faculty (advisors) in teaching activities. The advisor v/s scholars' ratio may also maintain at all level. Higher Education Commission of Pakistan must formulate criteria for research degree admission in order to ensure the enrollment of self-motivated and hardworking individuals. And continuously audit research degree 
awarding institute to ensure advisor v/s scholars' ratio. Further recommend that there may be host factors affect research degree completion so that further research study is required to be conducted on other factors augmented with these in different contents and context. 


\section{References}

Afzal, S., Arshad, M., Saleem, S., \& Farooq, O. (2019). The impact of perceived supervisor support on employees' turnover intention and task performance: Mediation of self-efficacy. Journal of Management Development.

Allen, D. G., \& Shanock, L. R. (2013). Perceived organizational support and embeddedness as key mechanisms connecting socialization tactics to commitment and turnover among new employees. Journal of Organizational Behavior, 34(3), 350-369.

Association for Support of Graduate Students (1993). Survey of Thesis Difficulties. Retrieved January 9, 2001 from the World Wide Web: http://www.asgs.org/1993_Svy.htm.

Bagaka's, J. G., Badillo, N., Bransteter, I., \& Rispinto, S. (2015). Exploring student success in a doctoral program: The power of mentorship and research engagement. International Journal of Doctoral Studies, 10, 323-342

Baird, L. (1990). The melancholy of anatomy: The personal and professional development of graduate and professional school students. In J. C. Smart (ed.), Higher education: Handbook of theory and research. (Vol. 6). New York: Agathon.

Baloyi, S., Van Waveren, C. C., \& Chan, K. Y. (2014). The role of supervisor support in predicting employee job satisfaction from their perception of the performance management system: A test of competing models in engineering environments. South African Journal of Industrial Engineering, 25(1), 85-95.

Bandura, A. (2012). On the Functional Properties of Perceived SelfEfficacy Revisited. Journal of Management, 38(9), 9-44.

Baran, B. E., Shanock, L. R., \& Miller, L. R. (2012). Advancing organizational support theory into the twenty-first century world of work. Journal of Business and Psychology, 27(2), 123-147.

Barclay, D. W., Higgins, C. A., \& Thompson, R. (1995). The partial least squares approach to causal modeling: personal computer adoption and use as illustration. Technology Studies, 2(2), 285- 309. 
Barrick, M. R., Mount, M. K., \& Judge, T. A. (2001). Personality and Performance at the Beginning of the New Millennium: What Do We Know and Where Do We Go Next. International Journal of Selection and Assessment, 9 (1/2), 9-30.

Bowen, W.G. \& Rudenstine ,N.L., (1992). In Pursuit of the Ph.D. Princeton, NJ: Princeton University Press.

Buhanan, A. L., \& Herubel, J. V. M. (1995). The doctor of philosophy degree: A selective, annotated bibliography. Westport, CT: Greenwood Press.

Caprara, Vecchione, M., Alessandri, G., Gerbino, M., \& Barbaranelli, G. (2011). The contribution of personality traits and self-efficacy beliefs to academic achievement: a longitudinal study. British Journal of Educational Psychology, 81, 78-96.

Carter, Wendy Y., (2004), Six major reasons why graduate students don't finish, Educational Group, L.L.C.

Chiappetta-Swanson, C., \& S. Watt. (2011). Good Practice in the Supervision and Mentoring of Postgraduate Students. Hamilton, Canada: McMaster University.

Cotterall, S. (2013). More than Just a Brain: Emotions and the Doctoral Experience. Higher Education Research \& Development 32 (2): 17487.

Council of Graduate Schools (CGS) (2017). Ph.D. Completion Project. [http://www.phdcompletion.org/]. Accessed 23 Aug 2019.

Cude, W. (2001). The PhD trap revisited. Toronto: Dundurn Press.

Daneil, I. L., Aziz, A., \& Tang, H. E. (2020). Refining the terminology of pre-higher education students: a quantitative study of entry qualifications, academic performance and family background. Borneo Akademika, 4(1), 25-37.

DeJoy, D. M., Della, L. J., Vandenberg, R. J., \& Wilson, M. G. (2010). Making work safer: Testing a model of social exchange and safety management. Journal of Safety Research, 41(2), 163-171.

Dinther, M. v., Dochy, F., \& Segers, M. (2011). Factors affecting students selfefficacy in higher education. Educational Research Review, 6, 95108. 
Dressel, P. L., \& Thompson, M. M. (1977). A degree for college teachers: The doctor of arts. Berkeley, CA: Carnegie Foundation.

Elgar, F. J. (2013). PhD degree completion in Canadian universities. Nova Scotia, Canada: Dalhousie University, 1-31.

Ellinger, A.D., Ellinger, A.E. \& Keller, S.B. 2003. Supervisory coaching behaviour, employee satisfaction, and warehouse employee performance: A dyadic perspective in the distribution industry, Human Resource Development Quarterly, 14(4), pp 435-458.

Fan, P. (2018). Person-organization fit, work-family balance, and work attitude: The moderated mediating effect of supervisor support. Social Behavior and Personality: an international journal, 46(6), 995-1010.

Felten, P., Gardner, J., Schroeder, C., Lambert, L., Barefoot, B., \& Hrabowski, F. (2016). The undergraduate experience: Focusing institutions on what matters most. San Francisco, CA: Jossey-Bass.

Feyter, T. D. Caers, R., Vigna, C. \& Berings, D. (2012). Unraveling the impact of Big Five personality traits on academic performance: The moderating and mediating effects of self-efficacy and academic motivation. Learning and individual Differences, 22(4) 439-448.

Fosse, T. H., Buch, R., Säfvenbom, R., \& Martinussen, M. (2015). The impact of personality and self-efficacy on academic and military performance: The mediating role of self-efficacy. Journal of Military Studies, 6(1), 47-65.

Frank J. E. (2003), PhD degree completion in Canadian universities. Nova Scotia, Canada: Dalhousie University, 1-31

George, D., \& Mallery, M. (2010). SPSS for Windows Step by Step: A Simple Guide and Reference (10th ed.). Boston, MA: Pearson.

Gliem, J. A., \& Gliem, R. R. (2003). Calculating, interpreting, and reporting Cronbach's alpha reliability coefficient for Likert-type scales. Midwest Research-to-Practice Conference in Adult, Continuing, and Community Education.

Gravois, J. (2007). In humanities, 10 years may not be enough to get a PhD. Chronicle of Higher Education, 53(47), A1.

Hair, JF, B Black, B Babin \& RE Babin (2010). Multivariate Data Analysis, 7th edn., Upper Saddle Creek, NJ: Prentice-Hall. 
Halbert, K., (2014), Factors affecting Doctoral progress: a report on the perspectives of Higher Degree by Research (HDR) candidates and their advisors, School of Education, James Cook University.

Higher Education Funding Council for England, (2010). Research Degree Qualification Rates. HEFCE July 2010/21. www.hefce.ac.uk

Hu, L. T., \& Bentler, P. M. (1999). Cutoff criteria for fit indexes in covariance structure analysis: Conventional criteria versus new alternatives. Structural equation modeling: a multidisciplinary journal, 6(1), 1-55.

Israel, G. D. (1992). Determining sample size.

Judge, T. A., \& Ilies, R. (2002). Relationship of Personality to Peformance Motivation. Journal of Applied Psychology, 87(4), 797-807.

Judge, T. A., Jackson, C. L., Shaw, J. C., \& Rich, B. A. S. a. B. L. (2007). SelfEfficacy and Work-Related Performance: The Intregral Role of Individual Differences. Journal of Applied Psychology, 92(1), 107127.

Kang, M.., (2004). Graduate attrition rate still a problem: Despite full funding few Ph.D. candidates complete programs. Columbia Daily Spectator.

Kerlin, B. A., (1998). "Pursuit of the Ph.D.: is it good for your health." Paper presented at the International Multidisciplinary Qualitative Health Research Conference, Vancouver, British Columbia, Canada.

Kluever, R. (1995) ABD's and Graduates from a College of Education: Responsibility, Barriers and Facilitators. Paper presented at the annual meeting of the American Educational Research Association, San Francisco, CA.

Kuh, G. D., Kinzie, J., Schuh, J. H., \& Whitt, E. J. (2005). Student success in college: Creating conditions that matter. San Francisco, CA: Jossey-Bass.

Leech, N., Barrett, K.C. \& Morgan, G.A. (2005). SPSS for Intermediate Statistics: Use and interpretation. (2nd ed.). London: Lawrence Erlbaum Associates.

Lei, S. (2016). Institutional characteristics affecting the educational experiences of undergraduate students: A review of literature. Education, 137(2), 117-122. 
McClenney, B. (2013). Leadership matters: Addressing the student success and completion agenda. New Directions for Community Colleges, 164, 7-16.

Nasr, P., \& Jackson-Harris, C. (2016). Identifying factors that influence student success in clinical laboratory sciences program. Clinical Laboratory Science, 29(4), 212-218.

Neill, J. T. (2016). The University Students Satisfaction and Time Management Questionnaire v.9

Neves, P., \& Champion, S. (2015). Core self-evaluations and workplace deviance: The role of resources and self-regulation. European Management Journal, 33(5), 381-391.

Odena, O., \& H. Burgess. (2012). "An Exploration of Academic Writing Development Across Research Degrees: The Students' Perspective." Paper presented at the British Educational Research Association (BERA) Annual Conference, Manchester, September 4-6.

Okesina, F. A. (2018). Influence of family background on academic performance of senior secondary school students as expressed by teachers in Ilorin Metropolis. KIU Journal of Humanities, 3(2), 163172.

Palmer, N. (2009). The Research Education Experience (I. Department of Innovation, Science and Research, Trans.): Council of Australian Postgraduate Associations.

Paltridge, B., \& L. Woodrow. (2012). "Thesis and Dissertation Writing: Moving Beyond the Text." In Academic Writing in a Second or Foreign Language, edited by R. Tang, 88-104. London: Continuum.

Park, C. (2007). Redefining the doctorate. York, UK: The Higher Education Academy. p. 4.

Pinson, C. G. (1997). Academic speed bumps: Time to completion of the dissertation. Virginia Polytechnic Institute and State University.

Poropat, A. E. (2009). A meta-Analysis of the Five-Factor Model of Personality and Academic Performance. Psychological Bulletin, 135(2), 322-338. 
Rachmawati, R., Octavia, E., Herawati, S. D., \& Sinaga, O. (2019). Culture, environment and e-learning as factor in student performance (case studies in management accounting study programs). Universal Journal of Educational Research, 7(4A), 72-78.

Ramos, M. G. (1994). Understanding the ABD (all but dissertation) doctoral candidate: A phenomenological approach. Unpublished doctoral dissertation, University of Kansas.

Richardson, M., Abraham, C., \& Bond, R. (2012). Psychological Correlates of University Students' Performance: A systematic Review and Meta-Analyses. Psychological Bulletin, 138(2), 353-387.

Rogers, C. R. (1969). Freedom to learn: A view of what education might become. Columbus, $\mathrm{OH}$ : Charles E. Merrill Publishing Co.

Sellman, W. S., Born, D. H., Stricland, W. J., \& Ross, J. J. (2010). Selection and Classification in the U.S. Military. In J. L. Farr \& N. T. Tippins (Eds.), Employee Selection (pp. 679-699). New York Routledge.

Slight, C. (2017). Postgraduate Research Experience Survey 2017.

Smallwood, S., (2004). Doctor dropout. The Chronicle of Higher Education, 50 (19).

Smith, N.-J. (2009). Achieving Your Professional Doctorate. Maidenhead: OU.

Stankov, L., Morony, S., \& Lee, Y. P. (2014). Confidence: the best noncognitive predictor of academic achievement?. Educational Psychology, 34(1), 9-28.

Stelnicki, A., Nordstokee, D., \& Saklofske, D. (2015). Who is the successful university student? An analysis of personal resources. Canadian Journal of Higher Education, 45(2), 214-228.

Sumathi, G. N., Kamalanabhan, T. J., \& Thenmozhi, M. (2015). Impact of work experiences on perceived organizational support: a study among healthcare professionals. AI \& Society, 30(2), 261-270.

Tabak, F., Nguyen, N., Basuray, T., \& Darrow, W. (2009). Exploring the impact of personality on performance: how time-on-task moderates the mediation by self-efficacy. Personality and Individual Differences, 47, 823-828. 
Tluczek, J. L. (1995). Obstacles and attitudes affecting graduate persistence in completing the doctoral dissertation. Unpublished doctoral dissertation, Wayne State University.

Tovar, E. (2015). The role of faculty, counselors, and support programs on Latino/community college students' success and intent to persist. Community College Review, 43(1), 46-71.

Turabieh, H., Al Azwari, S., Rokaya, M., Alosaimi, W., Alharbi, A., Alhakami, W., \& Alnfiai, M. (2021). Enhanced harris hawks optimization as a feature selection for the prediction of student performance. Computing, 1-22.

Van de Schoot, R., Yerkes, M. A., Mouw, J. M., \& Sonneveld, H. (2013). What took them so long? Explaining $\mathrm{PhD}$ delays among doctoral candidates. PloS one, 8(7).

Van Woerkom, M., \& Kroon, B. (2020). The effect of strengths-based performance appraisal on perceived supervisor support and the motivation to improve performance. Frontiers in Psychology, 11, 1883.

Vidak, M., Tokalic, R., Marusic, M., Puljak, L., \& Sapunar, D. (2017). Improving completion rates of students in biomedical $\mathrm{PhD}$ programs: an interventional study. BMC medical education, 17(1), 144.

Wang, X., \& L. Yang. (2012). "Problems and Strategies in Learning to Write a Thesis Proposal: A Study of Six Ma Students in a TEFL Program." Chinese Journal of Applied Linguistics 35(3): 324-41.

Wao, H. O., Dedrick, R. F., \& Ferron, J. M. (2011). Quantitizing text: using theme frequency and theme intensity to describe factors influencing time-to-doctorate. Quality \& Quantity, 45(4), 923-934.

Wisker, G., C. Morris, M. Cheng, R. Masika, M. Warnes, V. Trafford, G. Robinson, and J. Lilly. (2010). Doctoral Learning Journeys. Final report. www.heacademy.ac.uk

Zhang, Z., Nie, T., \& Xu, D. (2019). Family background, parenting practices, and child outcomes: Chinese migrants' offspring in Hong Kong. Chinese Journal of Sociology, 5(3), 263-282.

\section{Citation of this Article:}

Irshad, M. (2021). Etiology of students fail to complete doctorate degree within stipulated time. Pakistan Journal of Education, 38(1), 17-37. 
